УДК: 339.9

JEL Classification: F 020

(C) Sanotska K., Saienko O., Bilyk R., 2019

Yuriy Fedkovych Chernivtsi National University, Chernivtsi

\title{
UKRAINIAN-POLAND CROSS-BORDER COOPERATION : CURRENT SITUATION
}

The article analyzes the components of cross-border cooperation between Ukraine and Poland. The main directions of cooperation between the two States on a cross-border basis within the Euroregions are described. The article reveals the formation and development of Ukrainian-Polish cross-border cooperation. The author studies the formation of bilateral cooperation and analyzes the cooperation between Ukraine and Poland in the political, economic, trade and IT spheres. The theoretical aspects of cross-border cooperation between Ukraine and Poland. The state of international financial support for Ukraine cross-border cooperation projects. Identify priority directions of the state policy of cross-border cooperation of Ukraine.

Key words: Ukraine, Poland, cross-border cooperation, Euroregion, socio-economic potential.

Poland and Ukraine are the two biggest and most populated countries of Central and Eastern Europe. Because of their size, neighborhood and position in the region the two countries have often been compared to France and Germany. Both countries are deeply interested in their mutual cooperation. Such situation steams from five factors: direct neighborhood, common (albeit difficult) history, the attractiveness of the Polish labor market for the Ukrainians, membership of Poland in the Western structures, and last but not least, the Russian threat. Despite complementary interests, both countries have difficulty to effectively develop their mutual relations and turn them into a real "strategic partnership". These problems are due to the internal political and economic situation in Ukraine, limits imposed by the membership of Poland in the EU, Russian policy aiming at keeping Ukraine within its zone of influence and, finally, the EU reluctance to effectively engage in Ukraine.

Ukraine's cooperation with neighboring countries in Europe is very important in the context of the prospects entrance of our country to the European Union. The purpose of the article is an analysis of cross-border cooperation in the socioeconomic environment of Europe and the making of recommendations to enhance cross-border cooperation in Ukraine's new European integration environment. The cross-border cooperation between Ukraine and Poland will improve the economy and will get possibilities of new opportunities for each country.

Four objectives of cross-border cooperation are 1) supporting socio-economic development in regions on both sides of the common border; 2) joint actions towards common challenges in areas such as the environment, public health; 3) ensuring the effective and safe functioning of the borders; 4) supporting cross-border local community initiatives.
Both Ukraine and Poland should be working on their cross-border proximity partnership, as it bears an utmost signify cancer for Ukraine as a component of the European integration. It is very important to expand and develop a partnership between the two countries in connection with launching collaborative projects and developing cross-border proximity economic partnership. Establishing a collaborative institution of the type of economic partnership zone might help stir up external trade and ensure the ultimate abolition of restrictions on international trade as far as the most promising spheres of economy are considered.

Experience of the cross-border cooperation between Poland and Germany most likely lesson for the Polish-Ukrainian borderland. Since the fall of communism and German reunification, the cooperation between communities on both sides of the Polish-German border has been steadily gaining momentum. The first results were already visible in 1991 as the first Euroregion was established in Poland and the neighboring countries, the Neisse Euroregion on the Polish-German-Czech border. The later significant intensification of the crossborder cooperation was triggered by several historical events including the administrative reform in Poland (1999) and Poland's accession to the European Union (2004) and Schengen area (2007) these two recent events changed the appearance of the borders of both countries and opened new fields of cooperation in such areas as disaster prevention, public safety, health care, transport, education and others.

This experience is relevant for the PolishUkrainian borderland which presently undergoes similar processes like the ones observed between Poland and Germany before Poland's accession to the EU. For example, having modern border crossing points seems to be a much higher priority at this stage than e.g. having cross-border bicycle paths. 
However, the status of Ukraine as an associated country of the EU may open further perspectives for a more intense co-operation with its EU neighbors, including Poland. On the other hand, other domains such as joint anti-flood systems, school exchange programmers or capacity building are at this stage equally relevant in the case of Polish-German as well as Polish-Ukrainian borderland. Therefore, best-practice initiatives from the Polish-German borderland should be of great interest to those who envisage joint Polish-Ukrainian initiatives.
Despite the above-mentioned similarities, since the end of the communist system in 1989 - 1991, Poland and Ukraine have developed their foreign and security policies in different ways. Poland has realized a successful transformation, which led to its integration with NATO and EU, while Ukraine has remained a weak and unstable country on the peripheries of the Western system, which made it prone to the Russian aggression in $2014-2015$.

These differences have a considerable impact on the mutual relations between the two states.

Table 1

\section{Poland and Ukraine - principal differences}

\begin{tabular}{|c|c|c|}
\hline & Ukraine & Poland \\
\hline $\begin{array}{l}\text { History before } \\
1989-1991\end{array}$ & $\begin{array}{c}\text { Part of Soviet Union Strong oppressiveness of } \\
\text { the regime }\end{array}$ & $\begin{array}{c}\text { Part of the external Soviet empire Limited } \\
\text { oppressiveness of the regime }\end{array}$ \\
\hline Politics & $\begin{array}{c}\text { State-building } \\
\text { "Multi-vector" foreign policy }\end{array}$ & $\begin{array}{c}\text { Internal reforms } \\
\text { Pro-Western foreign policy }\end{array}$ \\
\hline Economy & "Shock without therapy" Oligarchization & $\begin{array}{l}\text { "Shock therapy" (Balcerowicz plan) } \\
\text { Foreign privatization }\end{array}$ \\
\hline Society & $\begin{array}{c}\text { Nation in statu nascendi Strong regional } \\
\text { differences }\end{array}$ & Nation-state Limited regional differences \\
\hline $\begin{array}{l}\text { International } \\
\text { environment }\end{array}$ & $\begin{array}{c}\text { No EU/NATO membership perspective Strong } \\
\text { Russian pressure (war in Donbas) }\end{array}$ & $\begin{array}{c}\text { NATO/EU accession Weak Russian } \\
\text { pressure }\end{array}$ \\
\hline
\end{tabular}

Cross-border cooperation is aimed at overcoming the negative effects of the existence of borders, in particular:

a) administrative and bureaucratic barriers between neighboring countries;

b) political obstacles to cross-border cooperation;

c) negative stereotypes and prejudices on both sides of the border;

d) insufficient social, cultural and economic infrastructure on both sides of the border.

Poland is the main trade partner of the Lviv region. After EU expansion in May 2004 the frontier regions of Ukraine that border on Poland got a competitive advantage related to the possibility of cross-border trade, cooperation and unique neighborhood conditions with the biggest integrated economic structure. At the same time, the principle and modus operandi of the Ukrainian-Polish trade changed - this has to do mainly with the institutional sphere. In this context, it is important to find new instruments and mechanisms that would help to transform the problems related to the expansion of the EU, and make the use of advantages and opportunities for Ukraine, strengthen national security and develop cross-border and regional cooperation. The further increase of external trade in the frontier regions of Ukraine and the use of advantages resulting from bordering on the EU will depend on the development of institutional infrastructure and dynamics of structural reforms in the field of Ukraine's external trade with the EU countries [2].

The Ukrainian-polish economic partnership is the main objective when it comes to finding sources of improving Ukraine's economic relations with the members of the EU at the current stage of European integration. Estimations based from January to June 2018 data show a promising tendency: The external trade in goods with Poland rose by 8.8 percent yearto-year, and that in services - by 38.6 percent. There is a rise in the proportion of Ukraine's trade operations with Poland (pro-rata to Ukraine's external trade operations). Trade turnover between the Polish and Ukraine in 2018 increased by $30 \%$ (compared to 2017). Poland Imports from Ukraine was increasing from year to year and continues to grow in nowadays. Ukraine Exports to Poland was US\$3.26 Billion during 2018, according to the United Nations COMTRADE database on international trade. Ukraine Exports to Poland - data, historical chart and statistics - was last updated in January of 2020. 


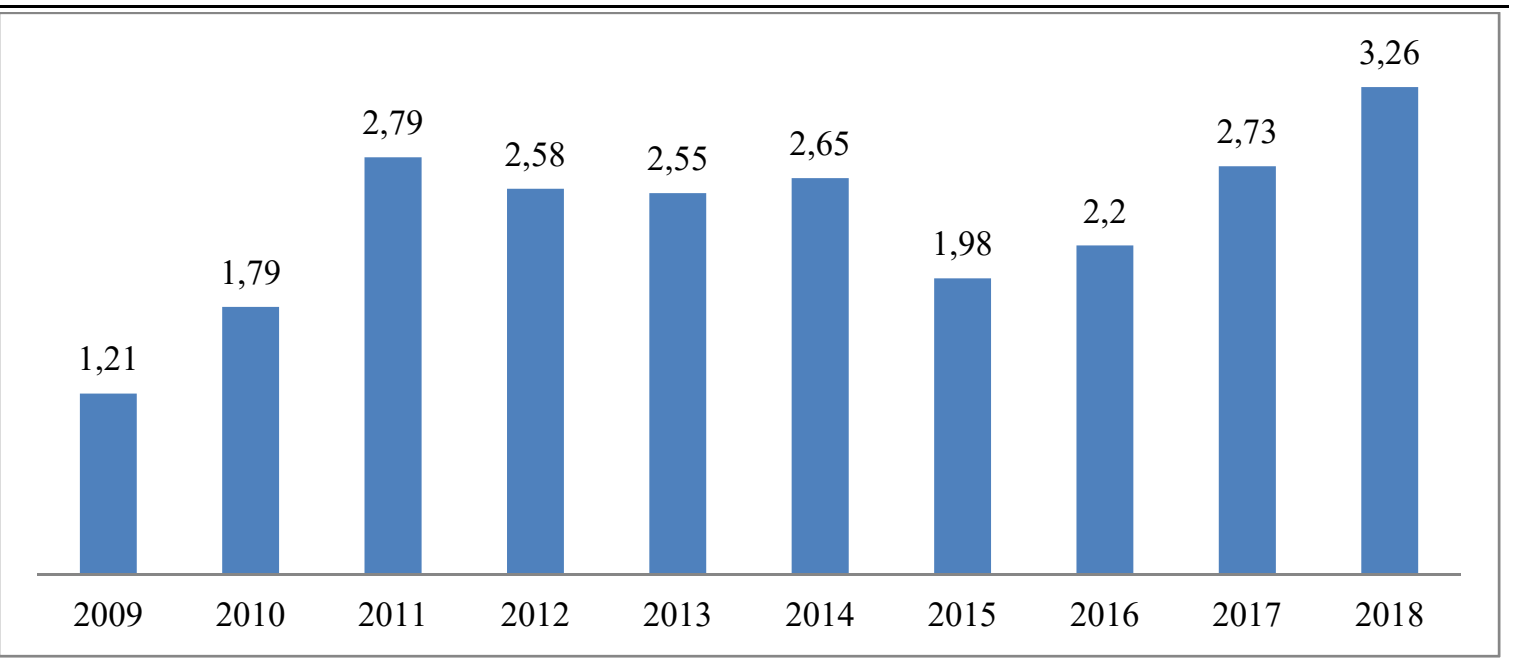

Figure 1. Ukraine Exports to Poland (US Billion) [2]

In the structure of imports of goods from Ukraine occupy the highest position in metallurgical and mineral products, their share amounts to about $30 \%$. Another item of imports from Ukraine is the agri-food products - $18 \%$, electrical industry products $14 \%$. The structure of Polish exports to

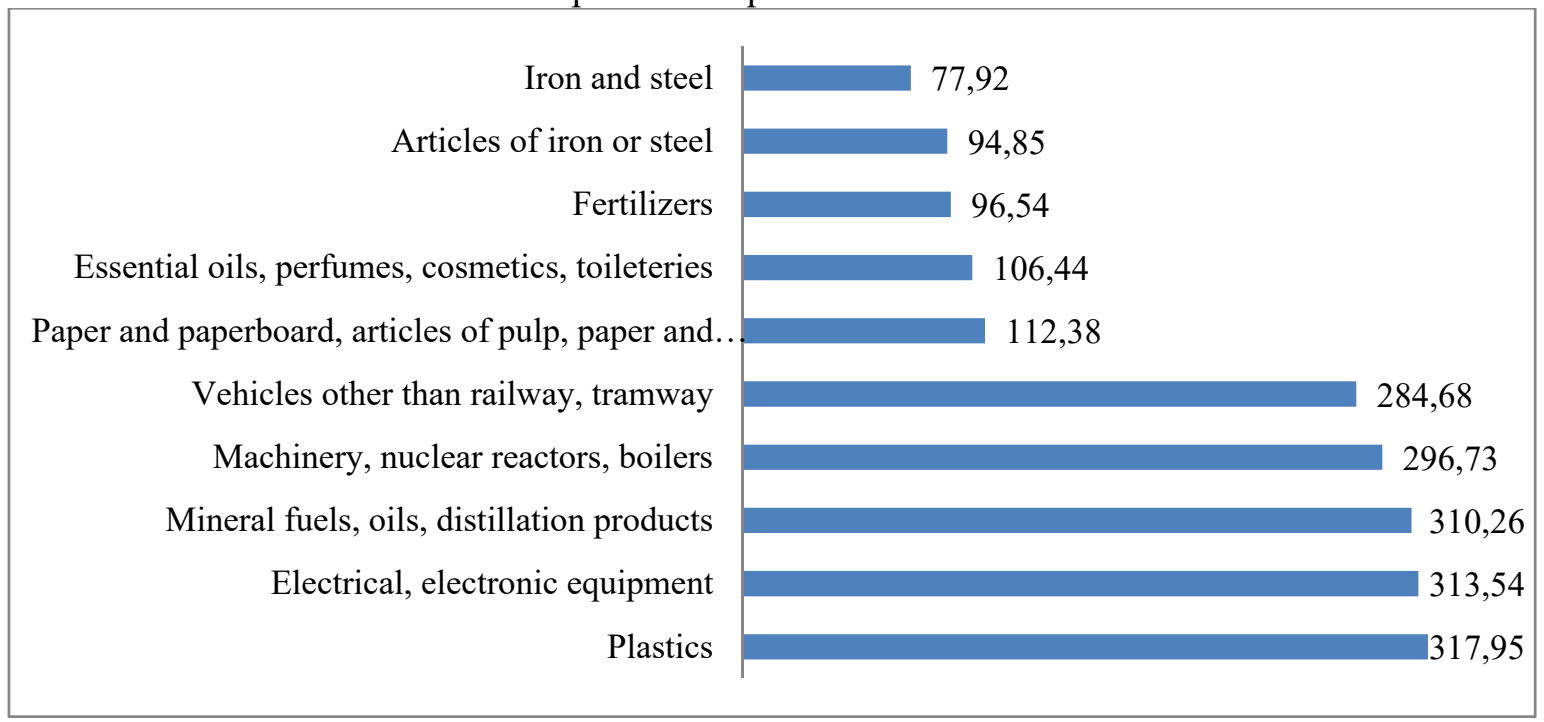

Figure 2. Ukraine imports from Poland 2018 (US Million) [2]

Large-scale "unofficial trade" was not directly influenced by Poland's accession to the EU. At least $40 \%$ of goods imported from Poland are in this category: more often than not these goods are registered at the Polish customs with the intention to reclaim VAT, but not custom cleared with the Ukrainian customs. This conclusion can be drawn from 90 analyses of the balance of the foreign trade between the Lviv region and Poland. According to some estimates, the official trade will also remain mostly uninfluenced in the nearest future. It is expected, that the percentage of legal trade will increase, while smuggling is going to decrease.
Ukraine in 2018 occupied the most important position in the mineral fuels, oils, distillation products $-20 \%$ of total exports to Ukraine. The next positions are products of the electrical industry $10 \%$, metallurgical products $-11 \%$ and agri-food products - $10 \%$.

Along with the stable growth of goods turnover, Ukraine's balance of foreign trade with Poland is deteriorating. The same can be said about the trade between the Lviv region and Poland after Poland joined the EU. In 2004-2016 the total balance of the region's foreign trade is negative, - 3949 mln USD. It is necessary to mention that numbers could be even worse if we had a correct estimate of illegal import happening over the Ukrainian-Polish border. There are considerable differences in the official estimates of the bilateral trade between Poland and Ukraine. 
As a result of the increase of bilateral trade, since the beginning of 2006 Poland became the main trade partner of the Lviv region, leaving behind the traditional leaders, Germany and the Russian Federation. In 2016 in the external trade of the Lviv region Poland comprised $24.9 \%$ of export and 27\% import. The second place belongs to Germany (12,2\% and $18 \%$, respectively), and the third one to the Czech Republic (7,3\% i 2,9\%).

Transboundary cooperation between Ukraine and Poland in the agrarian sector is an objective process with the condition of integration of the local economy into the global economy. Inter-regional 45 relations and foreign economic activity are developing, with joint ventures, holdings, and unions being created. This tendency is inherent to the countries having common borders, such as Ukraine and Poland in particular.

We consider the perspective directions of cooperation between Ukraine and Poland in the agrarian sector information of a coherent agrarian policy, the Common Agricultural Market, creation of a free trade area in the border regions, establishment of joint investment programs; improvement of the investment climate through preferential taxation of agricultural production; development of mechanisms for joint support of innovative activity of agricultural enterprises, farms, individual farms by regional authorities and local self-government bodies, etc. The cooperation between Ukraine and Poland in the agrarian sector will contribute to the economic development of both countries.

Another area of cooperation between Ukraine and Poland in the energy sector. It is relevant in the context of the integration of the economy into the world energy. It stimulates the development of interregional relations and foreign economic activity, as well as the creation of joint ventures, holdings and corporations. Such an opportunity exists when countries are interspersed and have common interests; in our case, this is the neighborhood of Ukraine and Poland [4].

One of the areas of cooperation between Ukraine and Poland in the energy sector is the creation of joint energy companies, as well as the formation of energy policy, creation of a common energy market, and mutual use of joint investment programs.

The research conducted by us established the main directions of Ukrainian-Polish cooperation in establishing relations between the two neighboring states in the field of energy in the border areas. Cooperation between Ukraine and Poland in the energy sector will contribute to improving the economic development of these countries.

Border territories of any country, regardless of its social and economic development status, usually remain on the periphery of its economic interests. Business gravitates towards the capital city and big economic and logistics hubs.

The main problem lies in overcoming the deformation in the structure of the economy of the border territories of Ukraine and Poland. The Ukrainian-Polish economic cooperation will be efficient only if it covers all spheres of the economy: industry, agriculture, transport, services, education, tourism, etc. The economic development of the border regions will help gradually eliminate the social foundations of "small business on the border", including the illegal trade of excisable goods, it will change the nature of this "small border traffic" [1; 4].

Consequently, a cross-border cooperation program formed by the governments of Ukraine and Poland must become the main instrument for overcoming the drawbacks of the market economy to ensure the even economic development of all regions of both the countries.

Innovative activity is an integral part of the modern world, which is developing dynamically. In Ukraine, among the innovative sectors of activity, the positive trend is demonstrated by the sphere of information technologies (IT), the future of which essentially depends on state support and changes in tax legislation.

At the beginning of its independence, Ukraine was at about the same level of socio-economic development as Poland. Today, this parity has changed, not in favor of Ukraine. In particular, the IT market in Poland is characterized by its high results.

The Ukrainian information technology market is represented by a number of IT companies, including SoftServe, Infopulse, GlobalLogic, EPAM, ELEKS, and others.

The IT sphere of Ukraine is largely internationalized and has close contacts with the professional environment in the countries of the European Union. Thus, this year, in January, SoftServe (specializing in software development) has completed the purchasing process of the Polish software developer Coders Center (specializing in ecommerce platforms). Ivano-Frankivsk's company Softjourn, which became one of the top 100 outsourcing companies in the world, has recently opened an office in Wroclaw, Poland.

The extension of the European Union creates opportunities for the development of cross-border cooperation, the realization of common interests of Ukraine and neighboring states, with the development of appropriate instruments for their stimulation. One of these tools is the development of the IT sphere, which dynamically integrates into all sectors of the world economy, directly affecting the 
overall growth of their economic and social indicators.

The Cross-border Cooperation Programme Poland-Belarus-Ukraine 2014-2020 is implemented under the European Neighbourhood Instrument and has been pursued for more than 15 years now since it was first launched in 2004 in the perspective for 2004-2006. Next, it was continued through the Financial Perspective 2007-2013 and is continued now, in the Financial Perspective 2014-2020. The main objective of the Programme is to support crossborder development processes taking place in the borderland between Poland, Belarus, and Ukraine. It means that it makes it possible for local communities to establish cooperation, gain new skills and experience, and thus offers opportunities to acquire funds necessary to stimulate local economic growth [4-5].

At the moment collaboration of Ukraine and Poland on cross-border issues benefits from the following $\mathrm{CBC}$ program within the European Neighbourhood and Partnership Instrument (ENPI): "Poland-Belarus-Ukraine", total sum of which for the whole program in 2014-2020 is EUR 202,959 million, EUR 186,201 million of which is provided by the EC and the rest is provided by the projects participants' co-financing (which is, according to the program rules, $10 \%$ of the amount granted). The priority areas of financial support flow are competitiveness of the border area, the life quality, networking and people-to-people collaboration. Thus, in 2009 environment improvement areas had total funding of EUR 133.1 million or $37 \%$ of the total funding for cross-border cooperation.

This program is a continuation and deepening of cooperation between the three neighboring countries, with the aim of promoting cross-border development processes.

Priorities: increasing competitiveness of the border area; improving the quality of life; networking and people-to-people co-operation. The area of the Programme is divided into basic and adjoining regions. The Programme covered areas lying directly or indirectly by the Polish-BelarusianUkrainian border with an area of 316.3 thousand $\mathrm{km} 2$. the main goals of the program such as better conditions for entrepreneurship, tourism development, development of regional and local opportunities for cross-border cooperation. And also for the future program was added the fourth priority, which includes such goals as support to border efficiency and security, improvement of border management operations, customs and visas procedures.

Having decided on becoming a partner of the European integration, Ukraine finds its first and foremost priority to be a cross-border proximity economy. The Ukrainian-Polish economic cooperation will be effective only if it covers all spheres of the economy: foreign trade, agriculture, energy, IT shere. The most important instrument for the competitiveness increase of Ukrainian border regions is the European Neighbourhood and Partnership Instrument, which includes some programs such a "Poland-Belarus-Ukraine 20072013 , and we have a continuation of this program in 2014-2020.

The development of Ukrainian-Polish crossborder cooperation has a number of specific features that make it different from other regions. First and foremost, the existing border was established in the middle of the XX century, and the historical memory of the cultural and economic features that existed here before Word War II is not fully lost yet. The purpose of the Polish-Ukrainian cross-border cooperation should consist of preservation and restoration of the Ukrainian, Polish, and Jewish historical heritage, the support of cross-border business infrastructure development, which in turn can contribute to overcoming of the existing problems of the frontier territories of both countries $[5$, c. 35$]$.

Cross-border cooperation, especially in Europe, has a number of similar problems having to do with establishing the state borders which often came as a result of political compromises. There are certain apprehensions and demands on both sides. An important humanitarian task of cross-border cooperation is overcoming prejudice and manifestations of national and religious hostility in mutual relations, as well as the support of friendly neighborhood relations at the frontier territories.

The main problem is overcoming the deformed economic structure of the frontier regions of Ukraine and Poland. The Ukrainian-Polish economic cooperation will be fruitful only if it embraces every sphere of the economy: manufacturing, agriculture, transport, services, education, tourism, etc. The development of the economy in the frontier regions will enable the destruction of the social basis for the so-called "small business at the border", including smuggling and illegal selling of excise products; this will change the nature of the "small cross-border movement". The market economy is not independently capable of solving the problems of the frontier territories. Therefore a program of crossborder cooperation developed by the governments of Ukraine and Poland should become the main instrument for addressing the imperfections of the market economy and moving towards the economic equality of the regions of both countries. 


\section{References}

1. Bil M., 2008. Transfrontier Collaboration Of Ukraine's Regions In Tourism Industry: Modern State And Basic Directions Of Development// Academic papers collection. Democratic Governance, http://archive.nbuv.gov.ua/ejournals/DeVr/2008_2/fail/Bil.pdf.

2. Boiko T., Gazizullin I., 2011. Report On The Competitiveness of The Regions Of Ukraine. Towards The Economic Growth And Prosperity. Effective Management, http://www.feg. org.ua/docs/Report_on_the_Competitiveness_of_Regions _of_Ukraine_2011.pdf.

3. Borko H., 2002. Paneuropean economic cooperation and its implications for the cross-border economic cooperation of Poland and Ukraine and Belarus. SGH, Warszawa, http://www.eadi.org/fileadmin/WG_Documents/Reg_WG /borko.pdf.

4. Borshch O., 2012. Cross-border cooperation as a development factor for borderline territories of Ukraine. Publisher: Springer Science+Business Media, European Journal of Law and Economics 20(12), http://link.springer.com/article/10.1007\%2Fs10657-0129363-y\#page-1.

5. European Neighbourhood And Partnership Instrument - Ukraine: Country Strategy Paper (20142020).

\section{Анотація}

Христина Саноцька, Олександр Саєнко, Руслана Білик

\section{УКРАЇНСЬКО-ПОЛЬСЬКЕ ТРАНСКОРДОННЕ СПІВРОБІТНИЦТВО : ПОТОЧНА СИТУАЦІЯ}

Проаналізовано складові частини транскордонного співробітництва Украйни і Польщі. Охарактеризовано основні напрями співробітниитва обох держав на транскордонній основі в межах єврорегіонів. Розкрито становлення і розвиток українсько-польського транскордонного співробітництва. Досліджено формування двостороннього співробітництвва й проаналізовано співпраџю України й Польщзі в політичній, економічній, торгівельній та IT сфері. Розглянено теоретичні аспекти транскордонного співробітництва України та Польщі, стан міжнародної фінансової підтримки проектів транскордонного співробітництва України. Визначено пріоритетні напрями державної політики прикордонного співробітництва Украӥни. Українськопольське економічне співробітництво буде плідни тільки в тому випадку, якщяо воно охопить усі сфери економіки: виробництво, сільське господарство, транспорт, сферу послуг, освіта, туризм.

Ключові слова: Украӥна, Польщза, транскордонне співробітництво, єврорегіон, соиіально-економічний потениіал.

\section{Аннотация}

Кристина Саночккая, Александр Саенко, Руслана Бильк

\section{УКРАИНСКО-ПОЛЬСКОЕ ТРАНСГРАНИЧНОЕ СОТРУДНИЧЕСТВО : ТЕКУЩАЯ СИТУАЦИЯ}

Проанализировано составные части трансграничного сотрудничества Украинь $и$ Польши. Охарактеризованы основные направления сотрудничества обоих государств на трансграничной основе в рамках еврорегионов. Раскрыто становление и развитие украинско-польского трансграничного сотрудничества. Исследовано формирование двустороннего сотрудничества и проанализировано сотрудничество Украинь и Польши в политической, экономической, торговой и IT сфере. Рассмотрень теоретические аспекты трансграничного сотрудничества Украины и Польши. Состояние международной финансовой поддержки проектов трансграничного сотрудничества Украины. Определены приоритетные направления государственной политики приграничного сотрудничества.

Ключевые слова: Украина, Польша, трансграничное сотрудничество, еврорегион, сочииальноэкономический потенциал. 